\title{
Pragmatics: the coming of age of a way of contemplating language
}

\author{
Pragmática: a chegada da maturidade de um modo de \\ contemplar a linguagem
}

\section{Kanavillil Rajagopalan Universidade Estadual de Campinas - Unicamp}

\section{Resumo}

Rastreio, em rápidas pinceladas, a história, no interior do paradigma gerativista, de atritos entre os defensores da semântica interpretativa e os da semântica gerativa, destacando os primeiros questionamentos que surgiram no campo e os problemas relacionados ao fenômeno de "verdade vácua". Em seguida, faço um breve apanhado da coligação entre sintaxe e semântica e posterior isolamento ou expurgo da pragmática dos centros das atenções. Apontando para os vestígios do milenar apego à lógica e ao formalismo e as dificuldades de se desvencilhar deles, pleiteio ousadia de procurar novos caminhos para investigação no campo, libertando-o das garras da lógica e encarando a pragmática como uma perspectiva sobre a linguagem, em vez de um mero componente.

\section{Palavras-chave}

Pragmática, Componente da gramática, Perspectiva sobre linguagem, Sintaxe / semântica.

\section{Abstract}

This article begins by tracing the tensions that existed between the proponents of interpretative semantics and those of generative 
pragmatics within the paradigm of generative linguistics, drawing special attention to the early discomfort with the phenomenon of "vacuous truth". This is followed by a rapid glance at the collusion between syntax and semantics, and the duo pitting itself against pragmatics, practically isolating pragmatics and relegating it to the status of a peripheral concern. Despite the permanence of vestigial traces of the fascination with logic and formalism, a clarion call for a bolder approach is made, one that will liberate pragmatics from the clutches of logic and begin to contemplate it as a perspective on the very phenomenon of language rather than a mere component of it.

\section{Keywords}

Pragmatics, Component of grammar, Perspective on language, Syntax / semantics. 


\section{The struggle between Syntax and Semantics}

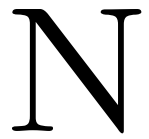

obody will dare deny today that pragmatics is a well-established field of study and research, with its own research agenda and priorities as well as a methodology uniquely (but, no doubt, somewhat looselyand with plenty of elbow-room*) tailored to meet its specific purposes. Gone are the days when scholars used to dismiss it as wanting in formal rigour and theoretical substance. Curiously, such allegations were implicit even in claims that were otherwise laudatory of its scientific credentials. A case in point is the following remark by ter Meulen:

Pragmatics, though less so than syntax and semantics, is characterized by a set of central research issues forming a coherent scientific program of linguistic inquiry. (TER MEULEN, 1988, p. 439).

The question to ask here is why at all should pragmatics be compared to syntax and semantics and its scientificity measured against that of these other two components of the semiotic trio, other than the mere historical accident that scholars started taking interest in it only after they had become convinced that the two components could not do the job by themselves.

Let us be clear about one thing straight away: historically, pragmatics did start its life rather timidly as an area worth looking into after the researchers had tried their level best to solve their problems by appealing to the theoretical apparatus developed in the so-called 'core' areas of linguistics, to wit syntax and semantics. In other words, pragmatics was their last resort and their first refuge! In their editorial to the very first issue of the Journal of Pragmatics, Haberland and Mey (1977, p. 7) jocosely summarized the prevailing attitude thus: "When in trouble call it pragmatics and jump."

Note that those who originally condescended (some time in the late 1960 s or the early 1970s) to admit that semantics could, after all, be credited 
with the right credentials to be considered a 'core' area had in mind solely 'formal semantics', an area of study that is basically a subfield of symbolic logic, with some minor readjustments here and there so as to take care of certain 'whimsicalities' that one associates ordinary, everyday language with (PIATTELLI-PALMARINI; CECCHETTO, 1997). This was also the period of an intense 'civil war' within the paradigm that used to be referred to at that time as the Transformational-Generative Grammar. The 'generative semanticists', as they came to be called, were engaged in a pitched battle with their adversaries who had sworn unswerving allegiance to the 'Aspects' model of grammar with syntax at its epicentre, endowed with all the generative power of language. In the preface to the second edition of his book Everything that Linguists Have Always Wanted to Know about Logic But Were Afraid to Ask, McCawley (1993 [1981], p. xii) admits that he had made "some bad decisions about the order in which to present things" and adds:

One of the bad decisions was to follow the usual practice of modern logic textbooks and present propositional logic before predicate logic. In the present volume, following the lead of Geach 1976, I have put the chapter on the "syntax" (formation rules and rules of inference) for predicate logic before the chapter on the syntax of propositional logic, thereby not only partially recapitulating the history of logic (Aristotle had a highly developed predicate logic two centuries before the Stoic logicians developed a full-fledged propositional logic) but also increasing the likelihood that my readers will come to share my view of the ubiquitous "unrestricted quantification" of modern formal logic as a pernicious aberration: (id. ibid.).

Some important comments on the passage just quoted are in order. First the scare-quotes on the first occurrence of the word syntax, in stark contrast with its conspicuous absence in the second occurrence of the same word a little later. I take it that McCawley is suggesting in a very subtle way that if at all one wants to insist that the formation rules and rules of inference of predicate logic constitute its syntax, one will first need to admit that one is using the word syntax rather loosely, as opposed to using the same word as applied to the same sort of rules and inferences of propositional logic. Now, what does it mean to say that 
one is using the word syntax loosely? The answer can only be that it is a syntax heavily under the influence of considerations that are, strictly speaking, semantic in nature. A syntax somewhat 'contaminated' by semantics, if you like! This is so because it has recourse to meaning, not just the mere 'concatenation' of morphemes or lexical items or whatever.

It also seems fairly evident to me that in raising the whole point about Aristotle and the Stoics, McCawley not only hopes to set the history of logic straight, but also drive in an important wedge that quantification must be subject to some mechanisms of restriction (and what else can those restrictions be if not semantic in their origin?). On this issue as well as the one about the shudder quotes on the word syntax mentioned in the foregoing paragraph, there can be no doubt that McCawley is making a case for generative semantics, whose fundamental claim was that syntax cannot operate on its own without availing itself of the fruits of semantics.

\section{Vacuous truth and some of the fallout from Aristotle's syllogistic}

McCawley did succeed in making some important inroads into the putative primacy and autonomy of propositional logic as a self-contained system. It is interesting to note here, however, that it was the very same argument that Fodor (1980) was using to a completely different end, roughly around the same time as McCawley's book first appeared. During the famous debate that took place between Chomsky and Piaget and their respective acolytes (PIATTELLI-PALMARINI, 1980), Fodor was eager to show that it was simply impossible to derive a comparatively richer system such as the predicate logic from a weaker one such as the propositional logic_an argument which he mobilized in order to prop up the Chomskyan position (and contra the Piagetian thesis) that the basic ingredients of the richer system had to be there already in the form of an innate endowment.

But it is important to recognize that the two lines of reasoning, Fodor's and McCawley's, are not on a collision course as they might strike one at first blush, nor did their proponents intend to cross swords. For one thing, they both agree that the propositional logic is poorer in its resources when compared to the predicate logic. The two however draw different conclusions from the same starting position. Unlike Ford, McCawley was interested in bringing up not only 
the limitations of propositional logic (i.e. the classic, Aristotelian logic of the 'square of oppositions'), but also a fundamental 'flaw', so to speak, in the argument that had for centuries nurtured the belief that it was a self-sustaining axiomatic system - the one that led to its dethronement and replacement by mathematical or symbolic logic.

However McCawley arguably left intact the Eukasiewiczian tradition (cf. $£$ UKASIEWICZ, 1957) of viewing Aristotle's syllogistic as an autonomous, axiomatised system. Now, what he stopped short of doing was pursue the full implications of whatever it was that had prompted Frege to raise his initial doubts concerning the autonomy of very enterprise called logic that long served as a battle-cry for its self-assumed role as the quintessence of pure reasonnamely, Frege's earth-shaking discovery that Aristotelian syllogistic only worked the way it had been shown to do provided one assumed a non-empty world (which clearly amounts to taking a metaphysical stance). Because, as Frege brilliantly showed, in the event of the universal being true, but only vacuously so, it cannot be claimed to entail its corresponding particular. This was after all, one of the principal justifications for Frege's argument that the so-called universal propositions are really conditionals bound by a universal quantifier, unlike the particulars in whose logical representation one is perfectly justified in using an existential quantifier. As a result, the formula $(\forall x)(P x \rightarrow Q x)$ cannot be said to be superordinate to $(\exists x)(P x \rightarrow Q x)$ the way the proponents of classical, Aristotelian logic thought that the universal proposition $p$ could be said to be superordinate to its corresponding particular $q$.

In retrospect, it seems fair to say that although the generative semanticists were able to make a serious dent into the position assumed by advocates of autonomous syntax, they were all too eager, right from the beginning, to 'contain', as it were, the consequences of such a move. In particular, they were concerned about the autonomy of the new amalgam of syntax-semantics duo. Once the sluice gates of system-external factors were prised open, no one knew for sure where it would all end. Therein may lie a possible explanation as to why there were so many attempts to sematicise new insights into the workings of language that were clearly pragmatic in nature.

The most notorious and perhaps the most well-documented of these attempts to sematicise pragmatics - and thereby to contain the threat it carried to wreck the ship of formalism — was Searle's attempt to reinvent J.L. Austin and 
his thoughts on speech acts (RAJAGOPALAN, 2000). This in turn spawned many other similar efforts in its wake. The most symptomatic of these was Ross's (1970) 'performative hypothesis' which was nothing but an effort to make the syntactic tree bear the forbidden pragmatic fruit_-by all means, no small feat! But others followed suit. Searle, who had set the stage for such dare-devil forays, was himself scandalised by what was going on and was forced to concede at one point:

The contemporary inclination to pack all sorts of things into phrase-structure trees even when they don't belong there does not arise simply from a fascination with a new analytical tool, rather the formulation itself makes it necessary to put this information in the trees because the notation provides no other way to represent it (SEARLE, 1976, p. 967).

\section{Syntax in collusion with Semantics against Pragmatics}

In the long 'civil war' within the generative paradigm between generative and interpretative semanticists, it is the latter that is widely believed to have carried the day (NEWMEYER, 1980), not because the former lost their ground and retreated in disgrace, but because the movement itself dissipated over the years, with its principal exponents, George Lakoff, James McCawley, John Robert Ross, and Paul Postal, each finding other more interesting things to do. Retrospectively, some observers of the scenario even argue that the position of generative semanticists was "unfairly suppressed" (SEUREN, 2004). As often happens in these cases, the victorious soon incorporated insights from the very group they claimed they had vanquished.

The paradigm as it emerged from the ruins of the bloody battle was in many ways unrecognizable from its early versions. It did stick to the centrality of syntax, but the syntax it now advocated was a syntax that had been enriched with some at least of what used to be semantics. As early as 1970, Langendoen (1970, p. 129) had noted:

Chomsky's conception of the nature of syntactic and semantic theory has gone through three major phases so far; each may be 
associated with a particular book. The first phase is marked by Syntactic Structures (1957); the second by Aspects of the Theory of Syntax (1965); the third by the newly published Studies on Semantics in Generative Grammar (The Hague: Mouton, 1972).

However, that was just a small taste of things to come. As we saw earlier, once the flood gates of semantics had been thrown open, it was only a matter of time before pragmatics would turn up for discussion. Thus, towards the end of the last century, we find Chomsky fumbling for an answer to a question from his interviewer as to whether or not pragmatics is to be considered part of linguistic competence and literally opting for verbal jugglery. Here's what he has to say in an interview conceded to Stemmer (1999, p. 393):

If we are using the term "competence" in my technical sense, then pragmatics is not part of a theory of linguistic competence, for uninteresting terminological reasons. If we are using the term "competence" in its ordinary English sense, then I suppose one might say that pragmatics is part of linguistic competence, but the conclusion is again uninteresting, merely a matter of terminology. I don't see any other way to interpret the question. Perhaps I am missing the point.

In other words, whatever be the answer it is sure to be "uninteresting". "So spare me the bother of having to parse your impertinent question," he might have added. What happened over the years was that, from the point of Chomsky and his acolytes, semantics was promoted from the status of a mere interpretative component of grammar as spelt out in the 'Aspects model' (CHOMSKY, 1965) to a pride of place as part of linguistic competence (in its 'technical' as well as 'ordinary English sense'), alongside syntax. In other words, all that occurred was a reshuffling of the classical components of grammar, with semantics migrating from the periphery to the centre and parting company with pragmatics for good.

As a matter of fact, the claim just made in the foregoing paragraph, needs some further qualification. It is not entirely correct to say that the whole of semantics was allowed to migrate from the periphery to the centre. Rather, what really happened was that semantics in its classical sense was imploded. And that 
seismic implosion took place exactly along the fault lines separating Frege's 'sense' (Sinn) and 'reference' (Bedeutung). Thereupon, the spoils were divided between syntax and pragmatics. Effectively, then, semantics became an empty component, simply a place-holder if you like, a buffer-zone between a vastly enriched syntax and a pragmatics, entrusted with the sole task of linking up with a language-external world "out there".

If Chomsky did get one thing straight, it was in respect of the very last sentence of his response (cited above) to Stemmer's query as to whether pragmatics should not be considered part of competence on the strength of Levinson's (1983, p. 34) argument that "there is some accepted component of grammar that is non-autonomous with respect to pragmatics (i.e. some component requiring pragmatic input)? If so, pragmatics must be logically prior to that component, and so must be included in an overall theory of linguistic competence". For, to be sure, he was missing an important point—as he himself rightly guessed!

Incidentally, there is a non-trivial point of comparison between McCawley's case for regarding predicate logic as deserving of being awarded priority over propositional logic and Levinson's argument that pragmatics must be deemed logically prior to "some accepted component of grammar". Grammar in the sense in which it is generally understood in linguistics - that is to say, as a self-contained system-is dependent on its very existence on a series of pragmatic suppositions, including 'suspension of disbeliefs'.

\section{Chomsky's curious adhesion to evolutionism}

The title of this section might understandably raise some eyebrows, especially in view of the fact that Chomsky's distancing from Darwinian evolutionism is no secret. His trade-mark claims of language as a species-specific attribute and instantaneous-acquisition of language have widely been interpreted as contrary to received wisdom in Darwinian biology. The truth of the matter is that Chomsky has been known to have changed his views with respect to the significance of evolution as far as human linguistic capacity is concerned. Thus alongside his confident assertion that "language must surely confer enormous evolutionary advantage" (CHOMSKY, 1975, p. 252), we also come across what turns out to be an about-turn when he says: "Evolutionary theory is informative 
about many things, but it has little to say, as of now, of the question of [language evolution]' (CHOMSKY, 1988, p. 167). Hymes (1991, p. 49) has gone on record as declaring that Chomsky's " $[\mathrm{h}]$ ostility to evolution as an explanation of the origin of language in the species goes hand in hand with hostility to experience as an explanation of the origin of linguistic form in the individual."

Against all this background, why is it important to insist on a certain parallelism between Chomsky's stance on the autonomy of syntax and evolutionism? The point of convergence is the unqualified adoption of the island metaphor by both.

In one form or another, island metaphors have been around for a long time. Oddly enough, they were widely used at the beginning of the $20^{\text {th }}$ century by anthropologists who argued for cultural relativism. The idea was that cultural isolationism, caused by insularity and lack of contact with the outside world, was just what was to be expected. Of course, the argument against any such talk of insularity had been eloquently put forward centuries before by the English metaphysical poet John Donne (1572-1631), when he wrote:

No man is an island entire of itself; every man is a piece of the continent, a part of the main; if a clod be washed away by the sea, Europe is the less, as well as if a promontory were, as well as any manner of thy friends or of thine own were; any man's death diminishes me, because I am involved in mankind. And therefore never send to know for whom the bell tolls; it tolls for thee.

But, from Chomsky's philosophical standpoint, every man is an island unto himself. Society (or 'the continent' in Donne's metaphor) has no place in the scheme of things. (cf. RAJAGOPALAN, 2006).

Eriksen (1993, p. 133) writes of the vitality of the island metaphor:

The island is a powerful metaphor in everyday speech as well as in several academic disciplines. The idea of the island connotes isolation and uniqueness; in biology, for example, the island metaphor is used in descriptions of isolated gene pools, divergent evolutionary patterns and closed ecosystems. Indeed, an image of nearly totemic stature and significance in modern biogeography and evolutionary theory is that of a literal archipelago, namely 
Galápagos' islands, which played a pivotal part in the development of Darwinism. In anthropology, too, island metaphors have had a strong attraction on the discipline's practitioners, and for similar reasons. Modern social anthropology was, as we are all aware, founded on an island, Kiriwina, in the Trobriand archipelago, which is in many ways to anthropology what the Galápagos' islands are to biology.

The island metaphor was at the heart of a major battle of wits in the field of anthropology in the early $20^{\text {th }}$ century between the advocates of evolutionism and those of what is referred to in the literature as diffusionism. The bone of contention was the precise role of external factors in influencing changes within.

Although the debate between the evolutionists and diffusionists centred on the question of how it was that tightly-knit social groupings underwent changes at all, the question itself has, mutatis mutandis, resonances with the problem taken up by Chomsky. In Chomsky's case, it is the individual that is in question. Chomsky is categorical in his claim that society plays no role whatsoever in the formation of the individual's identity and his growth, which for him is only a matter of fully manifesting themselves according to a preordained master-plan, built into his DNA (RAJAGOPALAN, 2006). The society has at best a "triggering" role in the process.

Needless to say, the evolutionist anthropologists of the early $20^{\text {th }}$ century and Chomskyan generativists of the late $20^{\text {th }}$ century are using the island metaphor to completely different and opposite ends. The evolutionists used the metaphor to bolster their thesis of cultural relativism. Chomsky, on the other hand, is anything but a relativist and his universalism is tied to his belief in the innate endowment that he thinks overrides any danger of unfettered dispersal.

But there is another aspect in which both the evolutionists and Chomsky are at one. And this had to do with the million-dollar question of whether or not changes can come from within a closely guarded system that is fully insulated from all its surroundings. Evolutionists reply in the affirmative and they attribute it to some innate endowment or genetic programming. So does Chomsky, for whom, given normal circumstances, a new born human baby it to some is predetermined, nay destined, to speak language, because the faculty of language is already prewired in its genetic makeup. The only difference between the two (and, mind you, it is nothing to be sneezed at!) is that the 
evolutionists treated that endowment as unfinished business, whereas for Chomsky homo sapiens already signifies a big leap forward in the evolutionary chain.

We shall take up this theme towards the end of this paper and see how this vital question has bearings on current developments in pragmatics.

\section{The lure of logic and formalism}

But the lure of logic has haunted scholars in pragmatics and keeps enticing and ensnaring them like the mythical Siren song. It is almost as if many felt that they could only claim scientific respectability for what they were saying by packaging it in the language of formalism. At the very least, many felt they had to pay it lip service at least. Many measure the merits of their own work against what formalist approaches have achieved, defining pragmatics sometimes in contraposition to it, sometimes as an addendum to it-but hardly ever in collision with it.

Take for example Grice's classic work on conversational postulates. Here's how Grice gets the ball rolling in his classic 1975 paper:

It is a commonplace of philosophical logic that there are, or appear to be, divergences in meaning between, on the one hand, at least some of what I shall call the formal devices $[\ldots]$ and, on the other, what are taken to be their analogs or counterparts in natural language [...] Some logicians may at some time have wanted to claim that there are in fact no such divergences; but such claims, if made at all, have been somewhat rashly made, and those suspected of making them have been subjected to some pretty rough handling. (GRICE, 1975, p. 41)

Having drawn the lines of the division, Grice proceeds to oppose the two groups whom he calls formalists and informalists and state their respective cases, albeit very sketchily. But then here is how Grice goes on to state his own specific objectives:

I shall confine myself to the dispute in its relation to the alleged divergences mentioned at the outset. I have, moreover, no intention 
of entering the fray on behalf of either contestant. I wish, rather, to maintain that the common assumption of the contestants that the divergences do in fact exist is (broadly speaking) a common mistake, and that the mistake arises from an inadequate attention to the nature and importance of the conditions governing conversation. (GRICE, 1975, p. 43)

So there is no conflict, nor can there ever be any conflict, between formal logic and informal ways of reasoning that we humans regularly resort to in dayto-day dealings with one another-if only for the reason that the two operate at different levels. Formal logic operates on the language as form. Informal logic works at the level of conversation, an activity in which we as social beings engage.

Furthermore, it is Grice's fundamental assumption that informal logic can only supplement, not contradict, what formal logic dictates. Think of his own example of a conversational implicature. The remark that someone makes about a friend who has recently started working at a bank in answer to a query by a common friend, namely, Oh quite well, 1 think; he likes his colleagues, and he hasn't been to prison yet, does implicate a number of things, among which the gruelling working schedule at a bank. What Grice is eager to press home is that a conversational implicature works by following logical reasoning through a somewhat tortuous path but never going against its dictates. In other words, pure logic is both the baseline as well as the limit of what we are allowed to do with ordinary language, no mater how illogical it may strike someone at first blush. Others like McGinn (1994, p. 587) go one step further to proclaim with confidence: "Pure logic takes possession of my reasoning processes and steers them according to its own dictates."

\section{Liberating human language from the clutches of logic}

It seems to me that the biggest challenge facing contemporary pragmatists is: how to liberate language from the shackles of logic. The relation between language and logic has a long history dating back centuries. Although scholars have long recognized that ordinary, everyday language does not necessarily obey the rules of logic, many have not been able to rid themselves altogether of their secret fascination with logic and the formal mechanisms that go along with it. As I observed in Rajagopalan (2008, p. 97), 
Indeed, so powerful has the temptation been to locate and identify a rational hard core in human languages that Leibniz, impressed by the beauty and perfection of the language of mathematics is believed to have exclaimed that, if God Almighty were to descend from Heaven and address ordinary mortals (all made after His own image, as the Bible tells us), he would speak to them in that language-it was simply inconceivable from the German philosopher's point of view that an all-perfect God would resort to any language other than the all-perfect language of mathematics.

In liberating pragmatics from the tyranny of logic that has so stifled reflection on language for centuries, the pragmatist has to contend with certain long-abiding prejudices that have prevailed in academia and act as stumbling blocks in her way. The first and foremost of these prejudices is the relative lack of prestige of the so-called 'soft sciences' that include basically the humanities. It is arguably the case that those scholars in the humanities who hanker after logic and formal techniques in their analysis are, often unbeknownst to themselves, making amends for their profound sense of an inferiority complex vis-à-vis their 'colleagues' in the 'hard sciences'. In the process, seldom do they worry about the possibility that in so forcing logic upon language, or rather, squeezing language into the moulds of logic, they may actually be engaged in a work similar to that of the mythical Procrustes.

\section{Approaching language from the perspective of "outside in"}

All this is not to deny that logic or logical reasoning has no role in language. But it is high time we debunked the idea that language is a phenomenon that revolves, as it were, around logic as its central core, an idea enshrined in such pronouncements as the following observation by Lyons (1968, p. 17) apropos the work Grammaire générale et raisonnée, popularly known as the Port-Royal Grammar (ARNAULD; LANCELOT, 1803), to the effect that its aim "was to demonstrate that the structure of language is a product of reason, and that the different languages of men are but varieties of a more general logical and rational system". If anything, the elevation of logic to such a status stands in need of close interrogation. At the very least, we must concede as a possibility of it being the case that the logical basis of language was the 
result of work done from the outside in rather than from the inside out. In other words, it was not what there was to begin with. Rather, it was the end result of concerted action by scholars determined to portray language as emanating from reason (RAJAGOPALAN, 2008). This was indeed the important question raised by Haberland and Mey (2002) as they surveyed the previous quarter century of work done in pragmatics and pondered future directions for research in the area.

Mey has been a key figure in urging researchers in pragmatics to view language from an eminently societal perspective, which means viewing language as just the visible tip of a much larger and formidable iceberg. As Mey (2010, p. 200-201) forcefully puts it,

What I am arguing for above is nothing but the need for a renewed consciousness of the human element in language use: an 'ecology' of language, as one could call it. Since languages are for use, the users of language deserve to be the prime center of attention when we talk or practice language use. But humans do not exist in some abstract conservation environment, where one can control their movements and monitor their speech, ensuring that they 'do the right thing'.

And humans, unlike robots pre-programmed to act and react in certain ways, do not play by the rules of logic. In the eloquent words of Cook (1990, p. 15)

Pragmatic philosophy is not, as it is often taken to be, a ready-made technique for analyzing occurring discourse. . The subjective, selective, and fundamentally unscientific nature of analysis of language in context should be acknowledged and not disguised by adopting the symbols and signs of more confident (if less exciting) approaches.

But there are always going to be voices of dissent coming from those who would rather have pragmatics going down the beaten track. As I insisted, in Rajagopalan (2005, p. 97),

When leading practitioners in the field of pragmatics like Mey (1985) and Verschueren $(1987,1999)$ plead that pragmatics 
should be viewed, not as a component of, but a perspective on, linguistics, they are issuing a clarion call for a radical rethinking of the way we researchers in pragmatics have historically conducted ourselves. They are exhorting us to rid ourselves of much of the inherited wisdom and endeavor to make pragmatics more "socially relevant" by directly addressing "society's need for language studies".

\section{Concluding remarks}

As one looks back over the years, one cannot but be impressed by the fact that pragmatics has grown by leaps and bounds. From its early beginnings as a field of marginal concerns, it has evolved to occupy the centre of attention of researchers in linguistics and neighbouring disciplines. Right at the outset of my contribution to the volume of papers in honour of Jacob L. Mey (RAJAGOPALAN, 2009, p. 335), I noted:

One of the most striking features of the field of study called pragmatics, as we survey its history in the last two or three decades, is its amazing metamorphosis, from a component of linguistics to a perspective of language and, in the ultimate analysis, as I shall argue, a perspective on linguistics.

The reason why pragmatics is entitled to being considered a perspective on the very enterprise of linguistics rather than a mere component of it is that it affords us a vantage point from which it becomes possible to contemplate how we came up with the very construct of language, to begin with. That is surely one way of embarking on our task of approaching subject matter from the outside in rather than from the inside out.

\section{Acknowledgements}

I wish to thank the CNPq, a funding agency maintained by Brazil's Ministry of Science and Technology for financing my research under grant no. 301589/ 2009-7. 


\section{Notes}

* This has primarily to do with the fact that the field is still developing at an amazing rate and is being vigorously pursued within different and often competing orientations.

\section{References}

ARNAULD, A.; LANCELOT, C. Grammaire générale et raisonnée de Port-Royal. Paris: Perlet, 1803.

CHOMSKY, N. A. Aspects of the Theory of Syntax. Cambridge, Mass.: The MIT Press, 1965.

CHOMSKY, N. A. Reflextions on Language. New York: Pantheon Books, 1975

CHOMSKY, N. A. Barriers. Cambridge, Mass: The MIT Press. 1988.

COOK, G. Transcribing infinity: problems of context and presentation. Journal of Pragmatics. 141, p. 1-14, 1990.

ERIKSEN, T. H. In which sense do cultural islands exist?. Social Anhropology, v.1. n. 19, p. $133-147,1993$.

FODOR, J. On the impossibility of acquiring 'more powerful structures'. In: PIATTELLI-PALMARINI, M. (Ed.). Language and Learning: The Debate Between Jean Piaget and Noam Chomsky. Harvard University Press, 1980. p. 142-162.

GRICE, H. P. Logic and conversation. In: COLE, P.; MORGAN, J. P. (Ed.). Syntax and Semantics. New York: Academic Press, 1975. p. 41-58.

HABERLAND, H.; MEY, J. L. Editorial: Linguistics and pragmatics. Journal of Pragmatics, v. 1, n.1, p. 1-12, 1977.

HABERLAND, H.; MEY, J. L. Editorial: linguistics and pragmatics, 25 years later. Journal of Pragmatics, v. 34, n. 12. p. 1671-1682, 2002.

HYMES, D. Is poetics original and functional? Language and Communication, v. 11. n. 2, p. 49-51, 1991..

LANGENDOEN, T. Chomsky on language. American Speech, v. 45, n. 1 / 2. p. 129-134, 1970.

LEVINSON, S. C. Pragmatics. Cambridge: Cambridge University Press, 1983.

$£$ UKASIEWICZ, J. Aristotle's Syllogistic from the Standpoint of Modern Formal Logic.

London: Oxford University Press, 1957. 
LYONS, J. Introduction to Theoretical Linguistics. London: Cambridge University Press, 1968.

MCCAWLEY, J. D. [1981]. Everything that Linguists Have Always Wanted to Know about Logic But Were Afraid to Ask. Second Edition. Chicago: Chicago University Press, 1993.

MCGINN, C. (1994) 'Thought'. In: GUTTENPLAN, S. (Ed.) A Companion to the Philosophy of Mind. Oxford: Basil Blackwell, 1994. p. 585=589.

MEY, J. L. Whose Language? A Study in Linguistic Pragmatics. Amsterdam: John Benjamins, 1985.

MEY, J. L. Current issues in societal pragmatics. Cadernos de Linguagem e Sociedade, n. 11, v. 1, p. 195-218, 2010.

NEWMEYER, F. Linguistic Theory in America: The First Quarter Century of Transformational Generative Grammar. New York: Academic Press, 1980.

ORENSTEIN, A. Reconciling Aristotle and Frege. Notre Dame Journal of Formal Logic, v. 40, n. 3, p. 391-413, 1999.

PIATTELLI-PALMARINI, M. (Ed.). Language and Learning: The Debate Between Jean Piaget and Noam Chomsky. London: Routledge and Kegan Paul, 1980.

PIATTELLI-PALMARINI, M.; CECCHETTO, C. The problem of meaning in generative grammar. In: MENDELL, C.; MCCABE, A. (Ed.). The Problem of Meaning: Behavioral and Cognitive Perspectives. Amsterdam: Elsevier Science Ltd, 1997.

RAJAGOPALAN, K. On Searle [on Austin] on language. Language \& Communication, 20, p. 347-391, 2000.

RAJAGOPALAN, K. Linguistic pragmatics: A discipline bedeviled by its own history? Implications for intercultural studies. Intercultural Pragmatics. v. 2, n.1, p. 93-97, 2005.

RAJAGOPALAN, K. Social aspects of Pragmatics. In: BROWN, Keith (Editor-inChief). Encyclopedia of Language \& Linguistics, Second Edition, v.11, p. 434-440. Oxford: Elsevier, 2006.

RAJAGOPALAN, K. Knowledge about language and emotion. In: CENOZ, J.; HORNBERGER, N. H. (Ed.). Encyclopedia of Language and Education. 2nd Edition, v. 6: Knowledge about Language, 2008. p. 93-104.

RAJAGOPALAN, K. Pragmatics today: from a component of linguistics to a perspective of language. In: FRASER, B.; TURNER, K. (Ed.). Language in Life, and a Life in Language: Jacob Mey - A Festschrift. Bingley, UK: Emerald Group Publishing Limited, 2009. p. 335-341. 
ROSS, J. R. On declarative sentences. In: JACOBS, R. A.; ROSENBAUM, P. S. (Ed.). Readings in English transformational grammar. Waltam, Mass.: Ginn \& Co., 1970. p. 222-272.

SEARLE, J. R. Review of Sadock's Toward a Linguistic Theory of Speech Acts. Language, n. 52, p. 966-971, 1976.

SEUREN, P. A. M. Chomsky's Minimalism. Oxford: Oxford University Press, 2004. STEMMER, B. An on-line interview with Noam Chomsky: On the nature of pragmatics and related issues. Brain and Language, v. 68, n. 3, p. 393-401, 1999.

TER MEULEN, A. G. B. Linguistics and the philosophy of language. In: NEWMEYER, F. J. (Ed.). Linguistics: The Cambridge Survey. v. 1. Linguistic Theory, Foundations. Cambridge: Cambridge University Press, 1988. p. 113-145.

VERSCHUEREN, J. The pragmatic perspective. In: VERSCHUEREN, J.; BERTUCCELLI-PAPI, M. (Ed.). The Pragmatic Perspective: Selected Papers from the 1985 International Pragmatics Conference. Amsterdam: John Benjamins, 1987. p. 3-8.

VERSCHUEREN, J. Understanding Pragmatics. London: Arnold, 1999. 